\title{
ПИТАННЯ ТЕОРЕТИЧНІ
}

DOI: $10.33608 / 0236-1477.2020 .02 .03-32$

УАК 82.091

Юрій БАРАБАШ, Аоктор фімологічних наук, професор Інститут світової Аітератури ім. О. М. Горького

Російської академії наук

ук.Поварская, 25а, Москва, 121069

e-mail: barabash.yuri@gmail.com

ORCID 0000-0002-8938-9408

\section{ЧУЖЕ-ІНАКШЕ-СВОЕ} ЕТНОКУАЬТУРНЕ ПОГРАНИЧЧЯ: КОНЦЕПТУААЬНИЙ, ТИПОАОГІЧНИЙ ТА СИТУАТИВНИЙ АСПЕКТИ

Це периа стаття авторського дискурсивного триптиха з проблематики етнокультурного пограниччя. У розвідиі визначено ключові теоретичні та методологічні принщипи підходу до етнокультурного пограниччя sк конщепту, вирізнено кілька його типологічних моделей (пограничні літературні зони, перехідні періоди та стани в літературному процесі, у творчості та психологіï того чи того мития, компаративні зіставлення тощо). Вибірково, під кутом зору світоглядно-філософської тріади «Чуже-Інакше-Своє», розглянуто приклади літературно-історичних ситуацій у геополітичних та етнокультурних зонах України, наразі - австро-украӥнського та польсько-українського.

Ключові слова: пограниччя, фронтир, конщепт, контекст, етнокультурна зона, типологія, модель, «Чуже-Інакще-Своє».

Від автора. Понад два десятиліття тому я надрукував російськомовну статтю (то була моя планова праця в Інституті світової літератури РАН) «К проблеме "конщь-переходы-начала". В связи с одной сковородинской реминисиенщией у И. Котляревского», і то у двох варіантах (часопис «Bопросы литературыь», 1997, №3, ma «імлійська» колективна праия «История наииональных литератур. Перечитыввая и переосмыссливая», выюп. III. Москва, 1998). Розгляд

Ци т в ан н я: Барабаш Ю. Чуже-Інакше-Своє. Етнокультурне пограниччя: концептуальний, типологічний та ситуативний аспекти // САово і Час. 2020. № 2 (710). C. 3-32. https://doi.org/10.33608/0236-1477.2020.02.3-32 
локального літературно-історичного епізоду - ймовірний, на думку деяких дослідників, відгомін пісні Г. Сковороди «Всякому городу нрав и права» у n’єсі I. Котляревського «Наталка Полтавка» та дискусї навколо ијєё версї - виводив автора статті до роздумів ширшого, загальнометодологічного плану, про «механізм» змінилітературних епох, напрямів, стильових течій. Хоча я покликався на Івана Франка, котрий дав нам «підказку», зазначивши, що Сковорода стояв на «розграні двох великих епох», проте вона мене тоді не підитовхнула до усвідомлення «пограниччя» як теоретично-методологічної проблеми. Це прийило пізніше. Тепер склався задум дискурсивного триптиха, до якого, крім статті, в якій ідеться про австро-украӥнську та польсько-украӥнську етнокультурні пограничні зони (вона друкується нижче), мають увійти ще дві студіі. В одній із них (другій у триптиху) планую подати розгляд східного етно- та лінгвокультурного пограниччя України: «харківський сетмент» (динаміка співвідношень украйнського і російськомовного культуротвірних чинників у літературному житті Харкова від середини ХІХ сm. до наших днів) та «донбаський сегмент» (зіставлення пов'язаних із донецьким краєм письменницьких доль і творчих феноменів на тлі сучасних драматичних подій у ретіоні). Третю студію (робота над нею на стадіі завермення) буде присвячено украйнсько-єврейському літературному пограниччю: єврейська тема в украйнській літературі (від Т. Шевченка до М. Бажана), украӥнські образи та мотиви у творчості письменників єврейського походження, так чи так пов'язаних з Україною (від К.-Е. Франиоза та Й. Рота до Шолом-Алейхема й Ш. Агнона), українські письменники - етнічні євреї (від К. Білиловського та Грицька Кернеренка до Аеоніда Первомайського та М. Фішбейна).

\section{Проблема Аавня/сьогочасна}

«Пограниччя - одне з найактуальніших і, може видатися, найсьогочасніших понять, із числа тих, які віднедавна ввійшли до термінологічного тезаурусу сучасної гуманістики; насправді ж воно має багатоступеневий родовіА, витоки якого сягають щонайменше початку нової ери.

Античним преАком «пограниччя» був римський «лімес»- корАон, прикордонна смуга, митна зона між Римською імперією і зовнішнім, «варварським», світом.

Значно ближчим хронологічно (хоча все ж із Аистанцією у століття із чвертю) попередником «пограниччя» сліА, певно, вважати «фронтир» - поняття, що його ввів Ао наукового вжитку асистент Вісконсинського університету Фредерік Ажексон Тернер у доповіді «Значення фронтиру в американській історії», виголошеній у Чикаго 12 мипня 1893 р. на з’їді Американської історичної асоціації; з'їзд проходив у рамцях Всесвітньої Колумбової виставки, присвяченої 400-річчю віАкриття Америки.

Поняття «фронтир» (англ. Frontier - «кордон», «рубіж») віА початку було прив'язане до специфічних умов та обставин доби освоєння американського Аикого Заходу й означувало рухомий цивікізаційний кордон поміж іще не освоєними і вже освоєними теренами, поміж незайманою природою і цивілізацією (за Тернером, це «точка зустрічі дикості зі цивілізацією»). Воно швиАко набуло попуцярності як компонент 
націонацьного історичного міту. Сформувався цілий шар пов'язаного $з$ фронтиром фольклору, зокрема т. зв. хвальківського гумору, а романтика підкорення нових теренів, образ фронтсмена, першопроходця, піонера та мисливця, мандрівного філософа, трикстера і просто пройди стали своєрідними мітературними архетипами (зокрема в доробку Ф. Купера, В. Ірвінга, В. Вітмена, Марка Твена). В американській історичній науці «фронтир» став одним із ключових термінів. На нього спирається «теорія кордону» (або «теза фронтиру» - англ. Frontier Thesis), яка впродовж кількох десятиліть практично домінувала в дослідженнях, присвячених американській історії, Аише в 30-х роках минулого століття ставши об'єктом критичного аналізу; втім інтерес до «фронтиру» i мітологічний «шлейф» у масовій американській свідомості, який його супроводжує, зберігаються досі.

Процес еволюції та трансформацій «тези фронтиру» в його первинному, Тернеровому, тлумаченні проходив (він не завершений до сьогодні) по кількох мініях і на різних рівнях. В узагацьненому плані його вектор можна означити таким чином: формування компаративного піАходу - як порівняльно-історичного, так і порівняльно-типологічного його варіантів, - до проблеми й, у цьому ракурсі, розширення просторово-географічних та історичних меж застосування теорії фронтиру, вихіА їі на інші, крім північноамериканського, ареали, переважно імперського типу, Ао колонізаційних та постколонізаційних аспектів. Такими $\epsilon$, до прикладу, студії Герберта Е. Болтона, Тернерового учня, президента Американської історичної асоціації, про іспанську колонізацію Аатинської Америки й про значення іспаномовного чинника («іспанський фронтир») Аля північноамериканської культури. Такими є також праці Оуена $\Lambda$ аттімора про «внутріазійські китайські фронтири»; вони присвячені проблемі «кордонів імперії», розглядові різних аспектів цієї проблеми - «природного» (географічні межі) та «штучного» (поАітичні й економічні чинники). Компаративістські досліАження низки американських і європейських авторів (А. Аедон, А. Рібер, А. ТредголА, А. Каппелер, Ю. Остергамель, В. Макніл) містять розгляд російського історичного фронтирного Аискурсу, позначений прямим або опосереАкованим впливом дихотомії місу і степу С. Соловйова, концепцій російських євразійців, зокрема, $\Lambda$. Гумільова, П. Савицького. На порубіжжі XX-XXI ст. у Східній Європі в умовах і внаслідок пов'язаних із розпадом Варшавського бцоку дезінтеграційних тенденцій та водночас із пошуком нових інтегративних чинників, активізувався інтерес історичної та культурологічної думки до фронтирних процесів на польсько-литовсько-білорусько-українському пограниччі, до етнокультурних традицій Великого князівства Аитовського та його столиці - Вільна [Аив.: 7, 36-47]; зокрема, в центрі уваги опиникася така знакова постать, як 
репрезентант цих традицій у наш час Чеслав Мілош, польський письменник-інтелектуал, мавреат Нобелівської преміі. Аослідник творчості Мілоша та його послідовник, польський письменник, культурний Аіяч Кшиштоф Чижевський на початку 90-х років створює в місті Сейни фунАацію «Пограниччя мистецтв, культур, народів» [Аив.: 33]. 2011 року Чижевський як преАставник фундації брав участь у підготовці та реалізації міжнародного проєкту «Уроки Мілоша для України», в рамцях якого у Аьвові, Аніпропетровську (нині Аніпро) та Харкові пройшли панельні Аискусії з фронтирної проблематики й різних аспектів Аіалогу цивілізацій у східноєвропейському регіоні в минулому та впродовж останніх років.

Радянська історична наука, в кожному - офіційний мейнстрим, до Тернерової теорії фронтиру ставилася зі стриманим, але позасумнівним критицизмом, їй закидали «нав'язування» тези про винятковий характер шляху історичного розвитку США, але насамперед звинувачували в недооцінці, ба більше - ігноруванні економічного чинника й класових суперечностей (останній закиА, сліА зазначити заради справеААивості, не був безпідставним). Аише в останні десятиліття в постраАянському науковому просторі з'явилися праці, в яких відчутне прагнення до об’єктивного анамізу американської концепції фронтиру, розробки системи критеріїв у визначенні соціопсхологічної та культурної природи фронтиру. Так, Н. Бєлаш, дослідниця проблем культурної географiï, головним критерієм, за яким фронтир/пограниччя відрізняється від решти території тієї або тієї країни, називає «чинник свободи» в широкому сенсі цього поняття - свободи віА підвалин і традицій, віА класових і станових умовностей, свободи віА державних, суспільних і правоохоронних структур, нарешті свободи Аля всіх, хто засемяє пограниччя, широкої, значною мірою стихійної демократії [Аив.: 4, 75-89]. У низці праць фронтирна теорія та методологія застосовуються щодо тих або тих аспектів історичної, географічної, етнографічної реацьності («Сибірський » $\mathrm{i}$ «івнічнокавказький» фронтири, австрійський т. зв. Військовий кордон на ААріатиці, «Степ» і пов'язані з ним різні форми номадизму, феномен козацтва).

В останньому випадку, в козацькознавчій проблематиці, яка традиційно посідає одне з кмючових місць в українській - так само й в інонаціональній, присвяченій Україні, - історіографії (пригадаймо поширений слоган «Ми - козацька нація»), помітна тенденція до зближення 3 компаративно-фронтирним напрямком у світовій науці. Історики намагаються, віАмовившись оА устацених стереотипів і засвоївши теоретичні та методологічні напрацювання в цій галузі, знайти нові піАходи до козакознавчого дискурсу, зокрема ті, що враховують чинник фронтиру. Інноваційну вагу маха під цим оглядом обгрунтована в працях Я. Ааш- 
кевича концепція Великого кордону (або, в декого з його послідовників, «Степового кордону»), іiі параметри визначаються чинниками як географічними та природними, так і цивікізаційними, соціоекономічними, етноконфесійними, етнокультурними $[14 ; 16]$. Низка студій з історії українського козацтва прямо зорієнтовані на концепцію Я. Аашкевича $[19 ; 21 ; 22 ; 5 ; 6]$. Помітний резонанс [Аив.: 20] викиикала монографія I. Чорновола «Компаративні фронтири» [34], в якій широке охоплення матеріалу з історії питання та високий рівень аналізу цього матеріалу поєАнані з постановкою актуацьних завдань, що, на думку автора, постають перед українською історіографією в ракурсі концепції компаративного фронтиру.

Важливий аспект згаданої дискусії, ширше - «фронтирного» Аискурсу як такого, - аспект термінологічний. Питання чіткості дефініцій та пов'язаних із ними сенсових акцентів набирає актуальності на тлі доволі широкого розкиду понять, уживаних у Аискурсивній практиці як парацельні поняттю «фронтир», а часом і як прямі його аналоги. Крім «пограниччя», у цій ролі зчаста виступають такі поняття, як «помежів'я», «прикордоння», польськ. — «кrеsу», англ. — «border», «borderland відмінності між ними часом стають предметом наукових суперечок [26]. Не вдаючися до детального розгляду цих суперечок, зазначмо, що віАмінності між різними позиціями дослідників стосуються (якщо, з необхідності, подати ситуацію в «укрупненому», тобто дещо схематизованому, вигляАі) двох аспектів. Це, по-перше, різниця поміж лінеарним піАходом до поняття «фронтир», однозначним тлумаченням його як роз'єАнувацьного кордону, border'a, і підходом просторовим, за яким фронтир - це смуга, перехідна, тобто практично з'єАнувацьна, зона; по-друге, поміж акцентуванням у дефініції «фронтиру» та його корелятів («пограниччя», «прикордоння», «кresy», «borderland ») геополітичного аспекту й визнанням як домінантних конотацій соціального, духовного плану - релігійних, етнічних, соціопсихологічних, культурних.

Польський дослідник С. УАьяш, автор книжки «Про мітературу кресів і пограниччя культур», вирізняє Аві форми культурного пограниччя: пограниччя стикове, із чіткою, незрідка жорсткою демаркаційною міні$є ю$, і перехідне, або перехідна зона. «На такому пограниччі з часом виникає певний тип суспільства та його культури. Аовготривалі явища та процеси взаємопроникнення або різних форм зіткнення культур впливають на формування певного типу особистості з вцастивою йому свідомістю <..> Проникнення та змішування культур перетворює пограниччя на перехіАний простір, своєрідний міст між взаємними цінностями куиьтур » $[40,10-11]$.

Ще сам «батько» фронтирної концепції, Тернер, завважував «гнучкість» головної дефініції. І справді, розрізнювальні ознаки поміж чле- 
нами таких, скажімо, дефінітивних конструкцій, як «фронтир-корАон» і «фронтир-зона», не завжАи виразні. Можливі обставини, коли опозиційний момент увіходить як одна зі складових у ширше поняття «зони», в середині якої створюється гостра «фронтирна ситуація» (Ао прикмаду, ініційовані губристичними мотиваціями спалахи застарілих міжетнічних або міжконфесійних конфціктів у традиційно устацених прикордонних зонах).

На сьогодні оптимацьним (у кожному разі, допоки не запропоновано іншого варіанта) стосовно етнокультурного аспекту видається термін «пограниччя», яким фахівці означують - слідом за О. Ааттімором, а в сучасній українській історичній науці за Я. Аашкевичем, - фронтир як зону інтенсивної взаємодії (вкцючно із суперечностями, з моментами протистояння) різних цивілізаційних векторів у поліконфесійному та помікультурному просторі ${ }^{1}$.

Слово Frontier до Тернера вживалося в Америці тільки в статистич-

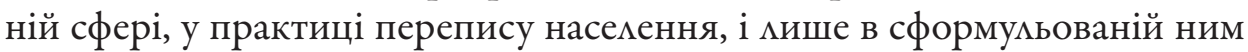
теорії набуло функції наукового терміна. Нині «фронтир» - як термін і як концепт, а також його сучасний трансформант «пограниччя» (не будемо заглиблюватися тут у зазначені повище тонкощі схожості й відмінностей) скцадають термінологічне ядро тезаурусу цілої наукової дисци-

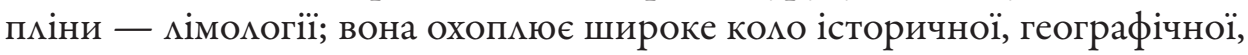
геополітичної, націологічної, соціокультурної проблематики. Процеси в цій галузі розвиваються за двома векторами.

«Фронтир/пограниччя» - феномен, у якому наука вгледіла колись характерну ознаку мокальної з погляду часу й простору ситуації, нині осмислюється гуманітарною свідомістю в контексті сучасного етапу світового історичного розвитку, як маркер нових рис та особцивостей цього етапу. Ааються взнаки процес глобалізації та притаманні йому такі риси й тенденціі, як множинність і ацьтернативність варіантів, непередбачуваність, часом химерність їх поєднань, різноманітність проміжних, амбівалентних форм і станів, які виникають на цій основі. Оприявнюються - хоч не завжАи чітко й повно - прикмети, характерні Аля історично-цивілізаційного пограниччя. Їх маємо підстави поцінувати як свідчення того, що в надрах сучасної культурної доби назріває стадія переходу до сутнісних, а може й докорінних, якісних зрушень (якого штибу - щодо цього є різні думки), ба більше, до якоїсь, можливо, цілком нової, цивікізаційної парадигми. 3 різних аспектів цієї пробле-

\footnotetext{
${ }^{1}$ I. Чорновол, так само означуючи фронтир як зону, а не роз'єАнувальну мінію, відАає перевагу таким аналогам Тернерового терміна, як «рубіж» і «порубіжжя», заперечуючи «пограниччя», яке ставить в один ряд із «кордоном». Не зовсім зрозуміло, які критерії покмав досліАник в основу протиставлення понять «рубіж» і «кордон», «порубіжжя» і «пограниччя».
} 
матики вже точаться дискусії в інтелектуацьній сфері й у спеціалізованих виданнях ${ }^{1}$.

Таким є один вектор процесу.

Інший (не другий, а саме іншиц̆, аж ніяк не другорядний) вектор пов'язаний із посиленням впливу ацьтернативних першому тенденцій, що формуються на периферії сучасного глобального тренду - здавалось би, всеосяжного. Кажемо «здавацось би» - бо сьогодні обидві тенденції постають не тільки (а певною мірою навіть не стільки) як різноспрямовані, а як різнорівневі, однак тісно між собою пов'язані моменти відштовхування та зближення. ГАобалізація та глокалізація - це два аспекти скцадного, суперечиивого, але суттю єдиного процесу. На його різних рівнях превалюють різні тенденції. Якщо, скажімо, в економіці, в сегментах, які стосуються матеріацьних параметрів життя суспільства та Аюдини, перед веде глобалізаційний тренд (хоча сьогодні стає дедалі очевидніше, що деякі конкретні форми його виявлення потребують критичного аналізу, якщо не перегляду), то в політичній сфері, в ідеологіі, надто в національних стосунках, в етнокультурній сфері й у внутрішніх процесах самої культури глокалізаційні, автономістські тенденції пручаються стандартизації, яка супроводжує глобалізацію, і нею, глобалізацією, породжуваній; тут домінує орієнтація на різноманітність, самобутність, «самість», на особистісне начало, на традицію і водночас на зухвалу новизну, яка «виламується» зі загацьно(«глобально»)прийнятої норми. Ця домінанта природним чином визначає наявність множинних форм, скцадної системи спів- і взаємостосунків між ними, тобто, якщо говорити про «фронтирне» начацо, то в потрактуванні, яке передбачає його коремяцію з такими поняттями, як кордон, погранична зона, перехідні форми й стани, амбівацентні тенденціі.

Останнім належить особлива роль у процесах духовно-культурного розвитку тих територіацьних утворень (країн, регіонів, «околиць», районів), Аля яких характерні геополітична хиткість, дуальність (така, що склалася історично або, поготів, штучно утворена), і як їх наслідок низький ступінь цегітимності, поліетнічний скцад населення, суттєві внутрішні мовні, релігійні, звичаєві відмінності, конфміктні «зарубки» в соціацьно-історичній пам'яті. Таких місцевостей аж надто багато в усьому світі, зокрема й у благополучному, «усталеному» Старому Світі. I то йдеться не про зони віАкритого конфміктного етнополітичного або етноконфесійного протистояння (Сербія - Косово, Каталонія - МаАриА, Північна Ірцандія), а про тихі, здавалось би «забуті», суто гумані-

\footnotetext{
${ }^{1}$ Згадуваний вище К. Чижевський пов'язує наближення «абсолютної зміни культурної парадигми» $з$ активізацією та поглибленням пограничних процесів у цій сфері (див.: [32]). Аив. також деякі матеріали, вміщені в мережевому журналі «Иначе», який послідовно Аотримується принципу альтернативності в обговоренні актуацьних проблем гуманітарної думки.
} 
тарні ситуації, пов’ язані, до прикмаду, з функціонуванням шотландської гельської та вамлійської мов у рамцях офіційної (та загальноприйнятої) англомовності, або окситанської (провансацьської) мови у Франції, або нідерландської в Бельгї.

У простороні колишніх Російської імперії та СРСР погранична проблематика актуалізувацася в пострадянських умовах, які, щоправда, зчаста поставаци у вузько потрактованих, «фронтирних» версіях; насправді мінійка таких версій, зрозуміла річ, суттєво ширша. Так чи так, націонацьні та історичні обра́зи, автономістські устремління, глокалізаційні тенденції, які до пори до часу дрімали або були загнані в підпімля, вийшли назовні, ба більше, набули загострення як у відносинах між деякими новоствореними чи віАновменими державами-сусідами, так і всередині окремих - якщо не більшості - з них.

Україна не стала винятком. Радше - характерним і прикметним «випаАком».

У самому націонацьному імені країни, етнонімі «Україна», яке етимологічно асоціюється з поняттям «край» - східний край європейського материка, західний край материка євразійського, відбиті ії пограничний статус і пов'язані з ним особливості історичної домі ${ }^{1}$. «Чинник пограниччя » сучасна українська та, значною мірою, світова гуманістика визнає одним із кАючових критеріїв Аля характеристики й оцінки низки суперечливих процесів націонацьної історії та культури, совєтського, а також постсовєтського етапів соціо- та етнокультурного розвитку, неординарних явищ, етнокультурних стосунків і взаємовпливів у пограничних зонах як у внутрішньому полікультурному просторі України, так і поміж Україною та аї сусідами на європейському і євразійському напрямках [Аив.: 16].

Традиція західноєвропейської україніки, тобто рецепції та вивчення в Європі України як історичного, геополітичного чинника й Ауховно-культурного феномену, має тисячолітні корені. А. Наливайко в присвяченій цій проблемі фундаментальній монографії «Очима Заходу» [Аив.: 24] простежує, в імагологічному плані, різні етапи проце-

\footnotetext{
${ }^{1}$ Я. Аашкевич, котрий дотримується цього погляду (на нього посилається і поділяє ці погляди

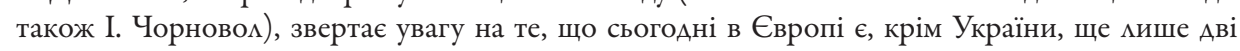
держави, які із часів середньовіччя зберегли в своєму імені вказівку на «окраїнний», пограничний статус, це Австрія (Österreich - Східна держава, що має СхіАний кордон [порубіжжя, пограниччя]), та Аанія (Danmark - «окраїна [Аілянка, кордон, пограниччя] данців»). С $\Lambda$ А зазначити (деталь вельми суттєва, хоча може здатися, що вона безпосередньо не тичеться до теми), що Я. Аашкевич поняття «окраїнності» як первинне Аля походження етноніма «Україна» (в Іпатї̈вському списку Київського мітопису віА 1187 року — «Оукраина») розглядає в контексті своєї полеміки щодо цього питання з колегами зі середовища українських істориків, уважаючи заперечення даного факту «парадоксальною (протилежною) реакцією» на «компмекс неповноцінності», «псевдопатріотичною фобією» (Аив.: [15, 93- 94]).
} 
су, починаючи віА Київської Русі, потім Галицько-Волинського князівства, Галицького (Руського) королівства (в захіАних Ажеремах — Regnum Galiciæ, Regnum Russiæ), через добу європейського Відродження до XVII-XVIII ст. - знаменитих праць Г. Боплана («Опис України») та Ж.-Б. Шерера («Аннали Малоросії). XIX століття дає прикцади художнього осягнення теми в європейському письменстві. У першій половині століття це поема Байрона «Мазепа» і твори представників польської «української школи» (Т. ПаАури, С. Гощинського, Ю. Б. Залеського, Ю. САовацького, М. Чайковського), у Аругій його половині - першій половині XX ст. українські мотиви знаходимо в доробку $\Lambda$. Захер-Мазоха, Р.-М. Рільке, К.-Е. Францоза, Й. Рота, Я. Івашкевича, С. Вінценза, Я. Парандовського, Є. Стемповського, Ю. Віттліна та ін. САіА, щоправда, брати до уваги, що форми та засоби втілення цих мотивів, ступінь аАекватності й глибини художнього освоєння проблематики відмінні в різних авторів. Ао того ж, здебільшого українська тематика становица мише частину творчої продукції цих мистців, найчастіше не головну (втім були винятки).

Зрозуміла річ, входження письменника в інонаціональне, іншомовне середовище, у світ інакших історичних і духовних традицій, специфічних ментальних особливостей, культурних цінностей і побутових звичок, навіть якщо цей світ через якісь обставини, з правила біографічного характеру, не зовсім чужий аця нього, та все ж не свій, у кожному разі інакшиц̆, - таке входження не може бути простим. Письменник опиняється в суперечцивій, не завжАи комфортній Аля нього атмосфері, яку визначає сукупність фронтирних, пограничних, перехідних станів; вектори динаміки та трансформації останніх можуть бути - і зчаста, якщо не зазвичай, насправді $\epsilon$ - різноспрямованими, зигзагоподібними, такими, що ведуть до далеко не завжАи передбачуваних наслідків.

У сучасній гуманістиці така ситуація розглядається в рамцях і піА кутом зору світоглядно-філософської та соціопсихологічної тріади «Чуже-Інакше-Своє». В останні роки спостерігаємо очевидну тенАенцію актуалізації проблематики, пов'язаної із цією тріадою, що, виАається, можна пояснити низкою об'єктивних чинників, які характеризують теперішню цивілізаційну добу. Це, наприклаА, дуже скмадна, сповнена драматизму діалектика процесів глобалізації/антиглобалізаціі/ глокалізації, які розгортаються у світі, та однієї з форм виявлення цих процесів - міграції. Вони виявикися несподіваними для західного по-

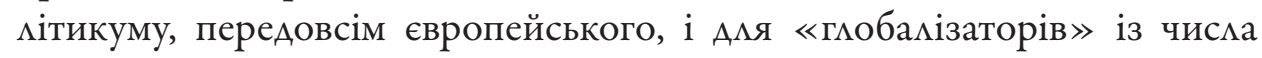
членів світової наукової гуманітарної спільноти, яких американський професор Ажеремі Адемьман називає «літописцями глобалізму», «гло- 
бальними істориками», які «втратими зв’ язок із сучасністю»ํ. Це також схожі ситуації в різних точках пострадянського простору, зокрема в етнокультурній сфері; на зміну деклараціям про «дружбу народів - Аружбу культур» приходять спроби об’ єктивного Аослідження реацьних пограничних явищ і процесів.

Низка публікацій у фахових наукових і мережевих виданнях присвячена широкому колу аспектів тріади «Своє-Інакше-Чуже», причім - слід завважити - iі радикальній (не просто скороченій) версії опозиції «Своє - Чуже» [Аив.: 42; 8]. Цей найдавніший «маркер» етнічної самоідентифікації особистості, один із константних концептів колективного світовідчуття, самосвідомості нації, розглядається в історичному ракурсі, на прикладах з історії філософської думки та мітератури: російської - західники/слов'янофіли, М. Гоголь, Ф. Аостоєвський, Вол. Соловйов, А. Карсавін, В. Набоков, української - Г. Сковорода, М. Гоголь (певними рисами своєї духовно-творчої сутності), Т. Шевченко, П. Куліш, М. Арагоманов, Ю. Шевемьов (особиста Аоля, також концепції «народники/модерністи», «європеїсти/органісти»). У схіАноєвропейській гуманістиці наприкінці минулого століття та в наступні роки, на тлі специфічних геополітичних обставин у регіоні, значний резонанс Аістали постколоніальні студії Е. Саїда, Г. Співак, Х. К. Бхабха; вони даци методологічні імпульси Аля аналогічних досліАжень на новому матеріалі.

Аедалі більшу увагу, однак, привертає в останні роки потрійна формула «Чуже-Інакше-Своє» та концепт етнокультурного пограниччя, який корелює із цією формулою. О. Сухомиинов, посилаючись на думку своєї польської колежанки М. Аомбровської-Партики, авторки книги « $\Lambda$ ітература пограниччя. Пограниччя мітератур» [36, 10-11], і виявмяючи солідарність із нею, пише: «У залежності від політичної та соціальної кон'юнктури у суспільній ієрархї̈ переважатимуть цінності одного з них (компонентів форми. - Ю. Б.), що є доказом основної дихотомї пограниччя, тобто постійного вибору між замкненістю у світі іАеології ксенофобії та толерантністю щодо Іншого» $[30,12]$.

Стимулювальну роль у дослідженні проблематики, пов'язаної 3 тріадою «Чуже-Інакше-Своє», відіграли ідеї та положення теорії

\footnotetext{
${ }^{1}$ У налрукованому 2 березня 2017 р. в цифровому журналі «Aeon » (офіси в Мондоні, Мельбурні та в Нью-Йорку) есеї «Що таке глобальна історія сьогодні?» А. ААельман визнає, що він і сам був таким «Аітописцем» і «зробив свій внесок у глобальний мейнстрим», очолюючи мабораторію ГАобальної історії в Принстонському університеті. Тепер стає очевидним, уважає він, що «необхідно змінити метафору» - відкинути уявлення про те, буцімто глобальна історія являє собою «емектричний манцюг», який «приносить світло всім, хто приєднався»; наспів час «позбутися наративів плаского світу» (приховане посикання на книгу Томаса Фрідмана «Пцаский світ. Коротка історія XXI століття». - Ю. Б.) та «невідворотної глобамізації (Аив.: [1]).
} 
Аіалогу: «чуже слово» М. Бахтіна, «діалогічний персоналізм» М. Бубера, «онтологія культури» В. Біблера. Принцип діалогізму доповнює та корегує жорстку формулу «Своє - Чуже», впроваАжуючи в неї момент толерантності за рахунок включення в дискурс поняття «Інакшого», внаслідок чого цей дискурс перемикається з режиму бінарної опозиційності («фімософія протистояння») на режим діалектики пограниччя («фінософія запитування» [рос. «вопрошания»]).

Аеякі аспекти, тенденції, конкретні приклади, переважно зі сфери української мітератури або з інших, якоюсь мірою пов'язаних із нею, розглянуто нижче, і то - сліА застерегтися напереА - без претензії, по-перше, на повне охопмення фактичного матеріалу (останнє взагалі навряд чи можливе, поготів у рамцях однієї статті), по-Аруге, на оптимальну глибину аналізу, яка може бути досягнута Аише на подальших етапах досліАження пробцематики; поки що вибірковість і оглядовість у підході до матеріалу, як видається, неминучі. При цьому сукупність наведених прикцадів (фрагментів, епізодів, «випадків») має не системний, а переважно мозаїчний (англ. patchwork) характер. Системний підхід до об'єкта - етнокультурного пограниччя (у широкому тлумаченні цього поняття) від початку не розглядається як інструмент аналізу через неієрархічність, фрагментарність цього об'єкта, несистемність як його родову ознаку. Предметами досліАження обрано значущі та репрезентативні, на погляд автора, регіони, ситуації, факти, явища, які вкцадаються в загальну схему типології етнокультурного пограниччя України. На цих прикладах висвітлено, ураховуючи специфіку кожного, «механізми» співвідношень, переходів і трансформацій усередині тріади «ЧужеІнакше-Своє».

Ще один суттєвий момент, що стосується методології аналізу. Такі особливості феномену пограниччя, як його несистемний характер, структурна неоднорідність, фмуктуаційність, множинність параметрів і хиткість кордонів, породжують у досліАника чітке відчуття недостатності традиційних методів, потреби оновцення та вдосконалення інструментарію. Цілковито очевидною постає доцільність методологічного плюралізму, доповнення (а в певному сенсі й корегування) звичних, хрестоматійних методів нетрадиційними, більш адекватними природі об'єкта науковими підходами, використання найновіших аналітичних практик. ПіА цим огмядом набирає актуальності синергетичний піАхіА як найбільш ефективний у досліАженні пограничних, перехідних явищ і процесів: так само можуть виявитися корисними - ясна річ, у певних межах і за умови дотримання норм методологічної коректності - поможення «естетики кореня» Жиля Аельоза та Фелікса Гваттарі, їхня теорія «ризоми» (франц. rhizome - коріння, коренева система), яка обгрунтовує принципово нелінеарне, неієрархічне потрактування поняття 
цілісності, відмову віА класичного уявлення про жорстко сфокусовану структуру (зокрема художню) на користь розгалуженого «корінняччя», акцент на гетерогенності сенсів, їх «плинності», на рухомості контурів і кордонів семантичного помя [Аив.: 15].

Анаціз проблеми у статті зАійснюється:

а) у конщептуальному аспекті, на рівні формування вихідних теоретичних позицій у підході до проблематики, критеріїв відбору фактів віАповідно до ознак, які характеризують поняття як концепт - не в універсальному (хоч за П. Абеляром, хоч за Аж. Аокком) тлумаченні, а в інтенсіонацьному, за Р. Карнапом, піА кутом зору сучасної теорії семантики; термін «концепт» (відповіАно похіАна мексема «концептуацьний») уживаємо в сенсі означення змісту поняття та визначення фунАаментальних відмінностей між фактами, вкАюченими до аналітичного поля, та позасистемним фактологічним матеріалом; цій проблематиці присвячено першу частину статті;

b) в аспекті типологічному, що передбачає створення типологічних рядів («типологія пограниччя») певної кількості пограничних мітературних явищ (історичних або сучасних), наприкцаА: пограничні мітературні зони в різних регіонах України; перехідні періоди та стани в Аітературно-історичному процесі, в мовній сфері, у творчості та психології того чи того митця, в розвиткові й трансформації традиційних форм; компаративні зіставцення, внутріжанрові, внутрітекстові, внутрімовні амбівалентні, перехідні форми та фронтирні ситуації тощо;

с) у ситуативному аспекті, в рамцях якого вибірково розглядаються конкретні прикцади пограничних ситуацій у діахронічному та синхронічному ракурсах, із урахуванням контекстуальних чинників - генетичного, історичного, геополітичного, соціо- та етнокуцьтурного.

\section{«Маленький західний півострів євразійського континенту» (Гамичина)}

У центрально-східній частині європейського мітературного процесу Аругої половини XIX - першої половини XX ст., конкретно — в його австрійському та польському сегментах, формується осібна течія, Ао якої належать письменники, котрі своїм походженням, біографічною пам'яттю, тією чи тією мірою рисами ментацітету й творчості були пов'язані з Галичиною, цим, за виразом Чеслава Мілоша, «маленьким західним півостровом євразійського континенту», або (мабуть, точніше) «східним півостровом Західної Європи», сказати б - «Сходом Заходу». Природа й характер цієї течії визначали два чинники: специфічні особливості Галичини як, по-перше, перехрестя історичних доль народів Центрально-Східної Європи, унікацьного мокусу етнокультурного по- 
граниччя - австро-польсько-українського (з різною мірою присутності єврейського, а також угорського, румунського, словацького, циганського елементів), по-друге - геополітичного перехрестя із притаманними йому національними, політичними, ментальними суперечностями, де важили взаємні обра́зи й претензії країн і народів - як закорінені в істоpiï, так і ті, що породжені катастрофічними пертурбаціями початку XX століття (світова війна, розвац імперій, перекроювання кордонів).

Тема Галичини у творчості австрійських і польських письменників співвідноситься з обома зазначеними чинниками; в етнокультурному пцані превацює чинник перший, що природно зв'язано з біографічною скцадовою, із забарвленою ностальгійним почуттям націонацьною пам'яттю про Аитячі роки, про мюдей, природу, традиції карпатського краю. В певному сенсі це були картини «втраченого раю», що залишився в минулому, але зберігся в пам'яті. У певному сенсі, проте, зрозуміла річ, не в повному, не вичерпному, адже пам'ять, звичайно, поповнювамася, часом і корегувалася, зрілою думкою, життєвим досвідом, і тоді в гармонію ідеального - або, точніше, такого, що здавався ідеальним, світу вторгалися історичні, соціацьні, політичні дисонанси, непривабливі реалії дійсності, національні, політичні чи попросту «надто Аюдські» упередження.

Інтерес до пробцематики, пов'язаної з етнокультурним простором Галичини як пограничного феномену, активізувався зокрема в польській та українській науковій спільноті віА 90-х років минулого століття. Це видана в Польщі англомовна колективна праця « від пост-війни до пост-модерну: місцевий путівник до глобального відображення» [38], студії І. Зимомрі, П. Рихла, Г. Грабовича, А. Цибенко, Т. Гавриліва, Я. Аопушанського, А. Айзенбарт; цю тему тією або тією мірою заторкнуто в монографіях, присвячених окремим представникам австрійської та польської мітератур новітнього часу.

\section{Австрійський сегмент}

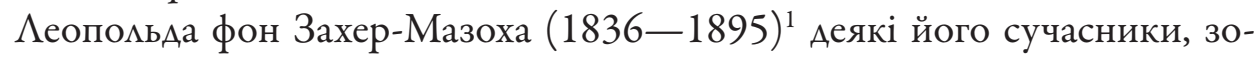
крема німецькі критики, називали галицьким письменником, настільки вони були вражені тим, як, із яким знанням і з яким щирим почуттям він писав про карпатський край; хтось шукав у його родоводі українську складову, хоча жодних документальних свідчень, які могли би потверАити цю версію, немає. Захер-Мазох був письменником австрійським і таким залишався у своїх «галицьких» творах, тож ближчими до істини

\footnotetext{
${ }^{1}$ Необхідне застереження. Аеякі положення та завваги цієї статті текстуацьно перегукуються 3 попередніми публікаціями автора (див.: [3]), однак треба наголосити на тому, що такі моменти, ширше - проблематика, кут зору на творчість письменника (йдеться, зокрема, про ЗахерМазоха та Вінценза) тут постають в іншому, ширшому мітературно-історичному контексті, в інших концептуальних і методологічних ракурсах, тобто в нових функціях і новому значенні.
} 
були критики в самій Галичині, які відзначали із задоволенням, що Захер-Мазох - «перший з чужинців», що та́к пише про неї. Цими творами автор розширив рамці європейської україніки, увівши в суспільний і мітературний контекст Європи тему Галичини. Можна висловити жаль із приводу того, що висновок віденського психіатра Р. Крафт-Ебінга щодо психопатологічної природи творчості Захер-Мазоха (висновок цей, треба визнати, спирається на реацьні особливості значної частини доробку прозаїка, що явцяє собою окрему тему) та - відповідно - термін «мазохізм» на довгі роки заступими в критиці й у читацькій свіАомості його «гацицький» творчий дискурс. Нині, з огляду на збагачення наукового арсеналу новими методологічними піАходами, зокрема піАходом кроскультурним, з'явилася можливість вивчати цю частку спадщини ЗахерМазоха піА кутом зору концептуальних і типологічних аспектів проблеми етнокультурного пограниччя.

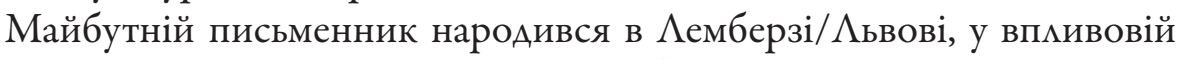
родині, яка мала повагу міської спільноти (батько, Аеопольд Стефан фон Захер, був значним австрійським урядовцем, начальником поліції Коро-

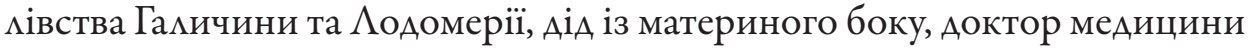
Франц фон Мазох, - депутатом Станового сейму, двічі обирався ректором $\Lambda$ ьвівського університету), там і проминули перші дванадцять років його життя [Аив.: 41; авторський синопсис книжки: 10]. У багатонаціо-

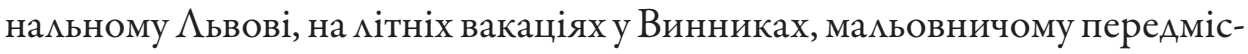
ті, у строкатому середовищі перевесників - Аітей польських шляхтичів, українських селян, єврейських крамарів, німецьких колоністів, хлопчик підростав у характерній Аля Галичини ситуації пограниччя. У мовному спектрі повсякденного спілкування друге - після польської (німецьку буде опановано пізніше) - місце посідама українська мова, точніше, їі гуцульський діалект, що його малий Аеопольд сприйняв через пісні, казки, мегенди віА няні Гандзі. Усім цим було закладено фундамент його Ауховного індигенату, який згодом давав письменникові почуття морацьного права, говорячи про Галичину, вживати займенникову формулу «в нас», а також ії семантичні кореляти - «ми», «наше», «тут», які природно вписувацися в оповідь від першої особи - форму, що ії ми часто зустрічаємо в текстах галицького циклу Захер-Мазоха.

Щоправда, семантичні та естетичні функції займенникової форму$\Lambda и \ll в$ нас» та ії корелятів можуть бути різними в різних текстах, іноді вони міняються місцями в межах одного тексту. Ця мінливість відбиває складні пограничні процеси всередині тріади «Чуже-Інакше-Своє», динаміку співвідношень поміж ії компонентами.

Приміром, у повісті «Венера в хутрі», одному з найвідоміших творів Захер-Мазоха, Галичини як такої практично немає, дарма що формально 
Аія відбувається в ії межах, однак пробцематика твору зовсім інакша Аля героя повісті Галичина $є$ не тільки не своєю, але навіть і не інакшою, це попросту щось геть відсутнє, тобто суттю чуже.

Інша річ - оповідання та нариси соціально-побутового, етнографічного плану («ХАопський суА», «Жіночі образки з Галичини»), твори різних жанрів, присвячені історичному минулому Галичини: романи «ОАна галицька історія. Рік 1846» і «Гайдамака», нариси та мегендарні новели про опришків, мандшафтні замацьовки та розгорнуті картини природи карпатського краю, до яких сучасний дослідник питання застосовує гайдеггерівське поняття «ментамьний мандшафт» $[31,372]$.

СліА, утім, підкреслити, що за всієї своєї симпатії до Галичини Захер-Мазох залишається австрійським письменником. Ним він постає, зокрема, у Аещо, сказать би, дражливому аспекті.

Річ у тому, що часом, і зазначмо - незрідка, це поняття виступає своєрідним маркером імперської свідомості, для якої Галичина - це «наші східні землі», частина Королівства Галіції та Һодомерії, коронної землі Габсбурзької монархії. Щось на зразок «галичинанаша»... Гацицький наратив письменника Захер-Мазоха перебивається голосом Захер-Мазоха - вірнопідАаного імперії, їі апологета; такі, наприкцаА, міркування автора у фінаці нарису «Жіночі образки з Галичини» про «австрійську расу» та роль у ії формуванні «галицької породи». 3 імперським тренАом пов'язана антипольська спрямованість низки творів Захер-Мазоха. От мише Ава прикцади. В оповіданнях про опришків наголошене їхнє протистояння польським «вельможним панам»; цей факт сам по собі не сприймається як порушення історичної правди, хоча тут ясно вловлюється нарочита акцентуація. Важливіше інше - відсутність у цій темі австрійського мотиву, добре відомого авторові, чий батько, як пам'ятаємо, значний поліцейський чин, брав активну участь у «замиренні» опришків. У нарисі «Свято обжинок» старий русин, наче здогадуючись, що́ віА нього хочуть почути, розповідає про тяжку селянську Аолю «піА польським пануванням» і висловлює велике задоволення тим, як, мовмяв, одразу стало мегше після переходу «піА Австрію», до «великого цісаря Йосифа»... Цей відгомін застарілих упереджень - приклаА, який висвічує одне з потенційно конфміктних явищ центрацьно-східного європейського пограниччя/фронтиру. «Нервом» цього регіону якраз і була Гамичина ${ }^{2}$.

\footnotetext{
${ }^{1}$ Сам Захер-Мазох у своїй «Прилозі» до «Венери в хутрі» говорив про «природну ворожнечу», навіть взаємну «ненависть» чоловічої та жіночої статей, яка одну зі сторін перетворює на молот, Аругу — на ковадмо [Аив.: 9].

${ }^{2}$ Унаслідок першого роздіку Польщі (1772) ці землі, під назвою «Галичина», увійшли до складу угорських Земемь корони Святого Іштвана, т. зв. Транслейтанії, частини Габсбурзької монархіï, яка пізніше дістала назву Австро-Угорщини.
} 
Важливим компонентом духовного світу й творчості Галичина (почасти Буковина) стала також у молодшого сучасника Захер-Мазоха Карла Емімя Францоза (1848-1904) ${ }^{1}$.

У біографіях та творчості обох неважко віАзначити пункти типологічної подібності, ясна річ, за відмінності деталей. Місто Чортків на Тернопімьщині, де минало дитинство Францоза, було Аля нього тим самим, що Винники для Захер-Мазоха: упадала в око етнічна та мовна строкатість оточення. Францоз у своїй єврейській родині виховувався в дусі поваги до німецьких гуманістичних традицій, але до німецької мови він прийшов Аише в німецькій гімназії в Чернівцях, в університетах Відня та Граца. Щоправда, в Чорткові на Францоза впливали інші чинники: польсько-українсько-єврейське мінгвопограниччя, одеське походження матері (за виразом Петра Рихла, ця «бабелівська» суміш української та іАишу звучала в його вухах «від самої колиски» $[28,7])$, українка-няня Мариня, котра називала хлопчика «Мільком» і залишила в його слуховій пам'яті, подібно як Гандзя в Захер-Мазоха, звучання української пісні, гуцульської говірки.

Такими були відпочаткові імпульси, передумови формування в обох письменників особливого інтересу, ба більше - сентименту до Галичини, що визначило важливе - не за обсягом, а за значенням, - місце й роль галицького Аискурсу в їхній творчості.

Що ж до конкретної реалізації цього дискурсу в текстах, то тут по-

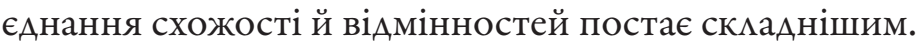

Живі національні типи, замальовки сільського побуту, галицької та буковинської природи, колоритні етнографічні подробиці в начерках й оповіданнях Францоза, присвячених Галичині, - «Повстання у Воловцях», «Війт із Бяли», «Ярмарковий день у Барнові», в романі «Боротьба за правду», виявлена в них позитивна стосовно галичан авторова позиція та доброзичлива інтонація «римуються» з особливостями нарисових творів Захер-Мазоха на аналогічні теми; проте слід говорити і про незбіги, причім суттеві, навіть принципові. ОАин із пунктів такого незбігу — польський мотив. У Захер-Мазоха він, як зазначалося вище, має чітко виявлений антипольський характер. Позиція Францоза у творах гострої соціальної спрямованості значно виваженіша, зображений ним польський поміщик Вініцентій, який поглумився наА українською Аівчиною («Повстання у Воловцях»), і австрійська адміністрація, що карає бунтівника, «гуцульського Карла Моора» («Боротьба за правду»), — явища одного штибу. Такий підхід Ао пробкеми, завважує

\footnotetext{
${ }^{1}$ Це прізвище (нім. Franzose - француз) австрійські чиновники, віАповідно до «Указу про терпимість» імператора Йосифа II, дали дідові письменника, оскільки його батько, М. Аевер (євр. Аеферт) 1770 року приїхав із родиною до Галичини (тоді це ще означало - до Польщі) з Франції.
} 
А. Наливайко, зближує ці твори з тим, що написали на ту ж тему Франко й Кобимянська, Стефаник і Марко Черемшина [Аив.: 25, 13].

Треба визнати, що певною мірою Францоз відАав данину ідеї інтеграції поліетнічного галицького компонента в німецькомовний культурний простір, але то була не імперіалістична стратегія, а радше своєрідна гуманітарна утопія, що ії живило схиляння перед традицією німецького гуманізму; вона передбачала не поглинення, не насильницьке підкорення, а міжнаціональний і міжкультурний діалог. «Міт Австрії, - пише K^аудіо Marрic, — як посередника поміж Сходом і Заходом знайшов у цих таємничих, відАалених краях (тобто на галицькому Grenzraum пограниччі. - Ю. Б.) свою духовну батьківщину» $[39,189]$. ОАним із виразників цієї тенденції був Францоз із притаманною йому високою мірою того, що можна назвати «інтеркультурною компетенцією».

Суттєвий момент відмінності поміж двома галицькими дискурсами - вихід Францоза за рамці Галичини, включення ії в загальноукраїнський контекст. У Захер-Мазоха такого контексту немає, поняття «Україна» він іноді згадує поряд із «Галичиною», але то мише згадки. Аля Францоза ці поняття невіАривні одне віА одного. СпогаА про сліпого кобзаря, побаченого в дитинстві на ярмарку («Ярмарковий день у Барнові»; Барнов - літературний «псевдонім» Чорткова, пор. Єгупець/ Київ у Шолом-Алейхема, Бучач/Шебуш у Шмуеля Аrнона), Аає імпульси роздумам письменника про українську думу як хранительку історичної народної пам'яті. У нарисі «Народна пісня малоросів» він розглядає козацькі думи в зіставленні з піснями гуцулів-опришків, підкреслюючи в них риси схожості і віАмінності, й звертаючи увагу на те, що, наприклаА, гуцульська пісня про Олексу Аовбуша здобула популярність на всій території України, зокрема на ії Сході. Прикметна піА цим оглядом назва книги Францоза, в якій уміщено цей нарис, — «BiА Аону до Аунаю». У цьому ж збірнику (2-е виА., 1888) Францоз друкує працю « $\Lambda$ ітература махоросів» - перший німецькомовний Аітературно-історичний огмяд віА «САова про похіА Ігорів» і Києво-Печерського патерика Ао нової української мітератури XIX ст. Особливий інтерес австрійського письменника викмикає творчість Т. Шевченка. Нагомошуючи на глибоко народній природі Шевченкової поезії, Францоз водночас (уперше в шевченкознавстві) обгрунтовує концепцію ії універсального, загальноАюАського значення, вписує спадщину Шевченка в європейський та світовий контекст [Аив.: 43, 36—43; 17, 52-55; 28].

Як бачимо, вихіА Францоза в загальноукраїнський простір 一 це не лише розширення фактологічних рамців, це заглиблення у фактологічний матеріал; репортажно-нарисове начало доповнюється, а значною мірою й витісняється, началом аналітичним. Утім процес амбівалентний. 3 одного боку, підвищується рівень змістової наповненості дискурсу, ва- 
гомості узагальнень і висновків, що, поза сумнівом, сприяє повнішому пізнанню об'єкта, тобто Галичини/України. ОАнак - Аругий бік питання - у певному, передовсім емоційному, сенсі це віАдацяє об'єкт віА реципієнта, знання якщо не витісняє рефлексії, живе, образне сприйняття, то в кожному разі відтісняє їх. Якщо, беручи це до уваги, а також під кутом зору тріади «Чуже-Інакше-Своє», порівняти галицькі дискурси Францоза і Захер-Мазоха, то можна завважити три моменти: а) дмя обох Галичина віА початку не була «чужою»; b) вона $€$ Аля них «інакшою» і приваблює до себе саме інакшістю; с) проте сприйняття цієї інакшості кожним з авторів має свої осібності; якщо Аля Францоза їі відчуття та усвідомлення $є$ головним, суттю незмінним, збагачуючись, розширюючи свої межі, воно не переходить ці межі, «інакше» залишається самим собою, «інакшим», то в Захер-Мазоха помічаємо ознаки внутрішнього руху до «свого», нехай не так чітко виявленого, це радше натяк, тренА, а не чітко виявлена риса, але натяк, тренд семантично значущий. Треба сказати, що вказані відмінності не несуть у собі оціночного сенсу за принципом краще/гірше, вони маркують різні особистісні версіі, різні концептуацьні та ситуативні аспекти етнокуцьтурного пограниччя як реацьності та як концепту.

Ще одна його австрійська версія - дискурс (тема, образ, мотив) Галичини в Йозефа Рота (1894-1939), письменника іншої генерації, ніж Захер-Мазох і Францоз. Із обома його зближує факт народження на галицькій землі - то було старовинне місто Броди, розташоване комись на кордоні між Гацицьким і Волинським князівствами, а на час народження Рота - поблизу кордону між Австро-Угорщиною та Росією. 3 Францозом Рота ріднить єврейське походження, хоча на відміну віА старшого колеги він походив із простої, не дуже заможної та не зовсім благополучної містечкової родини.

Ао «галицької версії» Йозефа Рота застосовні всі три компоненти етнокультурної тріади. Образ Галичини постає в сприйнятті й зображенні Рота як контрастна сукупність мінцивих співвідношень між поняттями «чуже», «інакше» та «своє», їх взаємозалежності та взаємозамінності, «перетікання» - найчастіше прихованого - одного в одне, ба більше - змінення суті й сенсу цих понять. Почасти тут дається взнаки суб'єктивний чинник - особливості стилю, творчої манери Рота, чия проза прикметна істотно більшою - порівняно з витриманою в традиційному стилі оповідною тканиною в Захер-Мазоха та Францоза - складністю структури, сенсовою багатозначністю. Але є також Аругий чинник, об'єктивний, пов’ язаний з історією, із Часом. Рот, його творчість, зокрема гацицький Аискурс, належить іншій добі - добі драматичних геополітичних пертурбацій у центрацьно-схіАному європейському регіоні, світової війни, розпаду Австро-Угорщини, післявоєнного 
передіку територій, заламання доль народів і мюдей... За часів Рота вже неможмиво було, зображаючи Галичину, обмежитися описами ярмарків та обжинкових свят, гуцульських звичаїв та обрядів, навіть злодіяння польських поміщиків і подвиги опришків відступали перед реальною історичною Арамою - драмою розриву зв'язку часів, утрати «великої», нехай і недосконалої, але батьківщини - Аунайської імперії та їі невіААільної (на думку Рота, й не тільки Рота) частини, «малої» батьківщини - Галичини.

Уявцення про цю нетривіальну австро-галицьку ідентичність письменника дає оповідання «ПогрудАя цісаря», передовсім образ його протагоніста.

...У галицькому сільці Лопатини мешкає граф Франц Ксаверій Морштин, виглядає, шо він колишній хазяїн села, втім, прямо про це немає мови, в кожному разі, мопатинцям здавалося, що «граф» - це не просто титул, а й назва дуже високої державної посади. Граф належав Ао Аавнього польського роду, який мав італійське коріння, проте він не вважав себе ні поляком, ні аристократом італійського походження. Він не належав до жодної нації, тобто був мюдиною «наднаціонацьною», мюдиною європейського світу. А відбитком цього світу була Аля нього цісарська монархія, саме вона, і тільки вона, була батьківщиною графа.

I раптом - геополітична катастрофа: у Відні помирає цісар, «єАина батьківщина» зруйнована, Аопатини опиняються на часовому та ситуативному фронтирі - у колишній Східній Галичині, теперішній Польщі; граф, який в уявленні мопатинців був вищим за будь-яку посадову інстанцію, вищим віА судАі та окружного начальника, граф, котрого знали й боялися селяни та євреї, - граф тепер, після поразки Австрії у війні, змушений вести перетрактації з польським воєводою, що приїхав із $\Lambda$ емберга, — цим, у його очах, «нікчемним помяком».

У Арамі, яку переживає граф, у його розгубценості, гніві, презирстві до тих, хто раніше всюди -у Тернополі, Сараєві, Відні, Брно, Чернівцях, ОАербурзі, Троппау — вважав себе австрійцями, а тепер став заявцяти про свою причетність до польської, чеської, української, румунської, словенської та якоїсь там іще «нації», - в усьому цьому вловлюється, за графовою іронічною інтонацією, відгомін почуттів і думок автора. 3бігу, звісно, немає, надто великою є дистанція між долями, але є близькі авторові, як і його персонажеві, гірка нота, сумний мотив утрати того, що здавалося надійним, неминущим.

У селі Аопатини коментатори впізнають селище Аопатин нинішнього Радехівського району Аьвівської області, куди Рот приїздив на відвідини свого гімназійного приятеля Мозеса Вассера. Можливий і ширший погляА: село асоціюється з Бродами, ба більше, з Галичиною, а Галичину Рот ототожнює з імперією, і це породжує - отакий психологічний 
парадокс - «роздвоєння культурно-політичної орієнтації» $[18,168]$. Галичина в уяві Рота більше не $є$ «своєю», вона набуває «чужих», неприйнятних рис, пов'язаних передовсім із загостренням націонацьних пробцем, яке його герой, граф Морштин, характеризував, посикаючись на Грільпарцера, формулою: «ВіА гуманізму через націоналізм до бестіамізму». Галичина як реацьність зникає із життя Рота, він полишає іï 1918 року, на фатальному пограниччі між «колишнім» і «сьогоднішнім», полишає практично назавжди.

Старезний, виснажений граф Морштин доживає свій вік на Рів'єрі, граючи вечорами в шахи або у скат із такими ж старими російськими генералами. У мемуарах він пише про свою «стару батьківщину», монархію, що вона була великим домом для різних мюдей. Тепер дім розділено, зруйновано, у ньому «більше немає місця» Аця нього. Так міг би сказати про себе й сам Рот.

Рот сумує не так за монархією, як за «великим домом» та своєю «кімнатою» в ньому - за Галичиною. Повертатися не було куди, «ве-

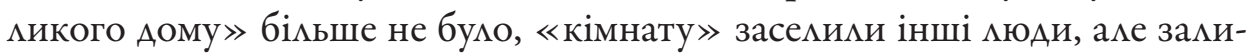
шалася можливість - іï ніхто не міг віАібрати - повернення метафізичного, Аумкою, пам'яттю, творчою уявою. Протягом своєї багатолітньої «втечі без кінця» («Die Flucht ohne Ende» - назва одного з романів Рота), пише АавіА Бронзен, перший біограф письменника, Рот «шукав свою втрачену вітчизну на багатьох станціях своїх безперервних блукань обхідними шляхами найвіАдаленіших країн ЗахіАної Європи. І знайшов iii у своєму художньому відтворенні східного світу» $[35,43]$.

Цим «східним світом» була Галичина. Вона присутня у Рота в багатьох творах, у різних формах — як образ, тема, сюжет, мотив, замацьовка, з різною мірою значущості семантичної та естетичної функції в структурі тексту.

Так, у ранньому, 1920 року, оповіданні «Петро Федорак» Гацичина «існує» тільки в роздумах і спогадах героя, галицького семянина, котрий, повертаючись на батьківщину з Канади, помирає у Вiдні, на Південному вокзалі, в очікуванні потягу. Означені в тексті три пункти - Канада, куди Петро їзив на заробітки, Відень - столиця імперії, яка щойно зникла («війна закінчилася») та безіменне галицьке село, де Петра чекали халупка під солом'яною стріхою, корова, свиня, жінка та Аитина, - ці три пункти визначають координати долі як героя оповідання, так і тисяч його земляків, властиво, усієї тодішньої Гацичини.

Герой роману «Йов» Мендель Зінгер, учитель із маленького галицького містечка, також, подібно до Петра Федорука, здійснює подорож за океан. Центрацьним тут виступає біблійний мотив праведника Йова. На тлі випробувань, що їх Бог насимає на Менделя, у пам'яті та свідомості героя живуть як Ауховний та емоційний антипод ворожої чужи- 
ни (такою сприймають - суттю однаково - Америку юдей Мендель і Рот, який у зрілому віці схилявся до католицизму) картини «втраченого раю» - Галичини. У такому ж, опосередкованому, зображенні, через постаті представників гамицького єврейства - переписувача Тори Нухима Каптурака та торговця корахами Вошивка Печеника, означено тему Гацичини в оповіданні « $е$ евіатан».

У наступному після «Йова» романі Рота «Марш Радецького», найбільш відомому та значущому його творі, тема Галичини, зацишаючись, якщо судити за зовнішніми ознаками, на другому плані, усе ж переходить зі сфери спогадів і рефлексій на рівень реацьності. 3'являються персонажі-галичани - денщик Онуфрій, помічник місничого Ян Степанюк; дія, починаючи зі середини тексту, переноситься до Східної Галичини. Ми впізнаємо іï у прикордонній смузі між Австрією і Росією; тут, у не названому автором типовому гацицькому містечку з десятьма тисячами мешканців, розмістився австрійський єгерський батацьйон, у якому служитиме мейтенант Карл Йозеф фон Тротта; поблизу розташоване село Бурцаки, батьківщина Онуфрія. Саме цьому краю судицося стати епіцентром подій, які започаткуваци воєнні та соціацьні потрясіння, що означими кінець Аунайської імперії.

Першим зустрічає війну строкатий натовп мешканців прикордонного галицького містечка - своєрідна етномодель усієї Галичини: українські селяни, євреї, шваби, помяки, крамарі, ремісники, чиновники. На стінах хати митного сторожа розвішені величезні плакати різними мовами, усі починаються зверненням цісаря «Ао моїх народів!». Знакова Аля цього прикордонного регіону постать польського графа Хойницького, Азеркальна версія іншого графа, фон Морштина, символізує дия Рота зміну геополітичного статусу Галичини з австрійського на польський, а деградація графа як особистості (в кінці оповіді фон Тротта-старший віАвідує його в божевільні) - історично тимчасовий характер цієї зміни.

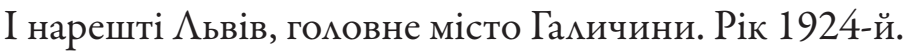

Нідерландський журналіст Ян Пауль Гінріхс у своїй книжці «Фа-

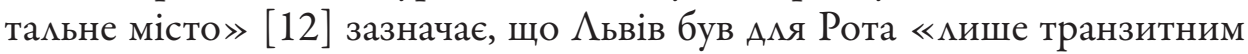
пунктом» у його подорожі. 3 формального боку, можна й так сказати, Аьвів Аійсно увіходив до маршруту великого європейського турне прозаїка - на той час кореспондента газети «Frankfurter Zeitung». Насправді ж мотив Аьвова став найважливішим, у певному сенсі переламним, пунктом у гацицькому Аискурсі Рота.

Аьвів означив новий кут зору письменника на Галичину. «Своя» Галичина залишилася в минулому разом із «великою батьківщиною», імперією; розчинилося в часі, зникло і сприйняття ії як «чужої», що виникло в трагічний момент розпаду Австро-Угорщини. Вкцючені Ао журналістського триптиха («Frankfurter Zeitung», 20, 22 і 23 мютого 


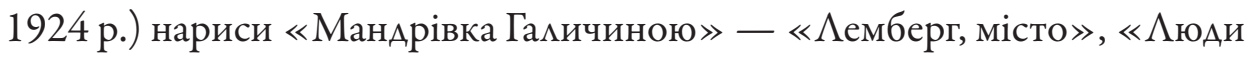
і місцевість» (нім. Gegend, «край»), «ІнваліАи» [29] сприймаються в цілості; це відкриття автором нової, «інакшої» Галичини - відкриття не тільки Аля себе, але Аля світу, передовсім Аля Європи. На тлі забарвмених ностальгією рефлексій Рот із роздратуванням, у якому чітко вловмюємо образу за близьке, «своє», реагує на поширені в деяких колах Заходу банальні, «дешеві й заяложені» судження про Галичину - така собі «цивікізована пиха», втім, уточнює Рот, пиха «нафталінова» ${ }^{1}$. Так, погоджується він, Галичина - це бездоріжжя, криві тротуари, недомадна каналізація, так, бідність і темнота семянина, і погано облаштовані готелі, що їх описав АльфреА Аьоблін у книжці «Подорож Польщею», i на базарах продають примітивних дерев'яних бказнів, як у Європі двісті років тому. Так що ж, «Європа тут закінчимася?» — запитує Рот себе та інших, зокрема того ж Аьобліна, чию книжку він пізніше високо поцінуе у своїй рецензії («Frankfurter Zeitung», 31 січня 1926 р.), висловивши, однак, застереження, що все ж «шаблони заступили світ розумному споглядачеві». I віАповіАає: «Нi, не закінчилася». I річ не Аише в тому, що між Європою і цим краєм зберігається постійний і живий зв'язок, що тут

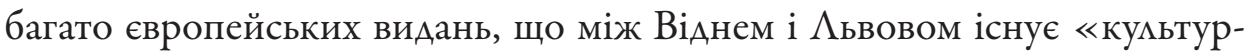

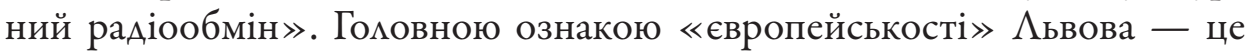
парадигмальна Ротова теза, рефрен його «Подорожі Галичиною» $-\epsilon$ національне та культурне розмаїття, мовне багатоголосся. $\Lambda$ ьвів — «барвиста пляма на сході Європи», за ним «починається Росія, інший світ». «Згідно з Ротом, - пише Т. Гавримів, $-\Lambda$ ьвів мовби покмиканий бути там, де кордон, однак бути там Аля того, щоб кордон розмивати, долати межі, Абати про розмаїття, бо розмаїття в Рота - більше ніж співіснування, це взаємопроникнення» $[11,108]$.

Метафора такого пограниччя, окремий випадок поширеного в Аітературі архетипу Аому, - це, за Ротом, готель, притулок, нехай тимчасовий, різних Аюдей (Амя самого Рота, протягом двадцяти років європейського безхатька, він був постійним), зона переходу, проміжковий пункт між початком і кінцем шляху. Таким $є$ готель «Савой» у романі письменника «Готель “Савой” », топос-модемь чи то зникмої Габсбурзь-

\footnotetext{
${ }^{1}$ Слід зазначити, що поміж тими, хто за часів Рота критично сприймав «галичанство» (не Галичину як таку), зокрема такі його ознаки, як провінціалізм, сервільно-лояльне ставлення до австрійської монархії, нахиц до політичної кон'юнктурності, знаходимо не мише «нафта-

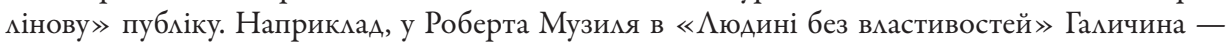
провінція країни «Каканії» (віА абревіатури К-K - kaiserlich-königlich), «кмята галицька глушина». Іван Франко різко критикував «мертве рутенство», що виступало хоч піА «українофільською» машкарою, хоч піА «москвофільською». У статті «Спогади М. Арагоманова» (Kurjer Lwowski, 24, 25, 30 травня 1890 р.) він солідаризується з автором тих спогадів, який характеризує свої взаємини з «австрійськими українцями», ширше - «галицькі та українські відносини, б’ ючи при цьому особливо по інертності, безпрограмності, Аегкості в зміні прапорів і крутійстві, де б і в якій формі вони не проявмялися».
} 


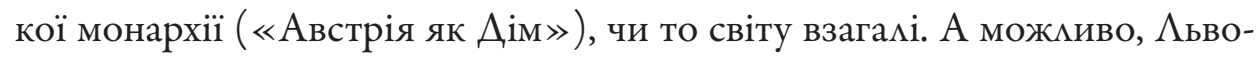
ва. Щоправда, прямого посилання на $\Lambda$ ьвів у книжці немає, та й готелю під назвою «Савой» у місті не було, але є дата написання твору, й вона якраз саме «львівська» - 1924 (Аив. вище). За Ротовим образом \ьвова, за його «мітом» постає вся Галичина, якою вона на ту пору бачилася письменникові, - уявною, ідеалізованою, «краєм націоналістичним par exellence».

\section{Польський сетмент}

Міт Аьвова, багатоликого, мінцивого (за Юрієм Андруховичем,

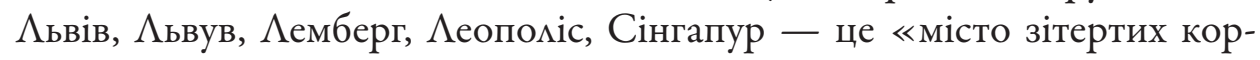
Аонів» [Аив: 2]), - пункт збциження, дотику Авох галицьких наративів, польського й австрійського. Зближення, Аотику й водночас протистояння. «Виникнення одного міту, - пише Г. Грабович, - вимагало виникнення іншого у відповідь. Як буває у майже всіх таких випадках, колективна самоідентифікація, “своє” чи “рідне”, визначається через протиставлення Іншому» $[13,157]$. Критик розглядає факти польської та української «мітологізацій» у підході до проблеми має загальнометодологічне значення, що, як виАається, робить можливим і коректним застосування його в австрій-

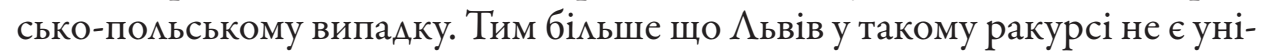
кальним. Критик посилається на низку схожих ситуацій із європейської історії: це Вільнюс, про який Чеслав Мілош, його уродженець, говорив,

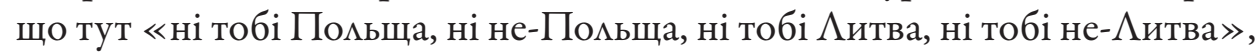
це польсько-німецькі Gdańsk/Danzig, Breslau/Wroclaw, Posen/Poznań, Stettin/Szczecin, італо-хорватські Trieste/Trst i Fiume/Rijeka, німецькорумунсько-українські Chernowitz/Cernauți/Чернівці.

Хрестоматійний історичний прикмаА - єврейсько-європейськоарабський (юдейсько-християнсько-мусульманський) Єрусалим. Звісно, завважує Г. Грабович, Аьвів виглядає скромно перед Єрусалимом, «але ступінь емоційного та психологічного наснаження суперечок за нього з обох сторін теж близький до граничного», Аьвів стає «АОсконацим об'єктивним корелятом наративів націонацьного самостверАження » $[13,157]$.

Тут у критика знову-таки йдеться про протистояння польсько-українських иьвівських мітологічних наративів. У польсько-австрійському випадку полемічний фронтир постає інакше, рівень напруженості загамом помітно нижчий, однак треба брати до уваги, що емоції та висловАювання учасників полеміки з різних сторін не симетричні щодо ступеня гостроти; це відбиває відмінність політичних і психологічних ситуацій, в умовах і на тлі яких формуються мьвівські й ширше - галицькі дискурси. Аіють чинники (скористуємося дихотомією Грабовича) «присутності та «відсутності . 
У свідомості Захер-Мазоха, в його картині світу Галичина - реально «присутній» об'єкт, частина габсбурзької імперії, стабільність якої не викликає в письменника сумнівів, тож антипольські мотиви та репліки, що трапляються в його галицьких творах, не мають агресивного характеру, в них відчутна інтонація поблажливості переможця - «учасника» роздіку Польщі. У польських авторів (зазначмо, не в усіх і не однаковою мірою) преванюють рефлексії переможеного. Вони знаходять вияв у різних варіантах концепції «інакшості». У Франтишека Яворського

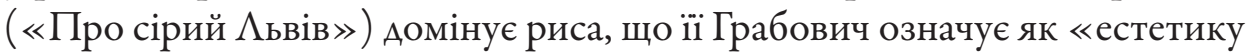
ностальгії та неприхованої емегійності». У книжці Станіслава Васимев-

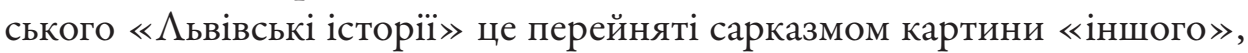

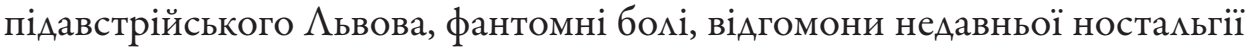
(книжка Василевського побачила світ 1921 року, коли Аьвів знову став польським) за втраченим, але нескореним «мевом», і це віра у «вічну

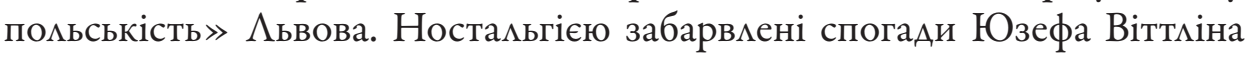

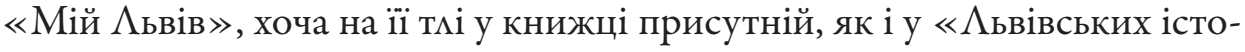
ріях» Яворського (втім це характерна риса «львівського наративу» загалом, різного авторства й різних часів), сміховий, анекдотичний, часом буфонадний струмінь в описах етнокультурних і побутових рис цього багатоукладного міста; у цих описах немає ідеологічного, поготів політичного підгрунтя, радше $€$ фантасмагорична, майже містична складова.

Навівши ці приклади «присутності» - у різних формах і різних співвідошеннях - австрійського та польського мотивів у польському мьвівському/галицькому дискурсі, звернімо увагу на значно суттєвіший момент «відсутності»: в цьому Аискурсі практично відсутній український компонент, автори зосереАжені Аише на польсько-австрійському протистоянні. Наче ні в доавстрійський період, ні в наступні часи на землі Галичини не було їі автохтонного насемення, українців. Г. Грабович у цьому зв'язку посилається — як на «ембцематичну» - на фундаментальну працю Вітольда Шолгіні про Аьвів, видану, між іншим, уже в 90-і роки минулого століття (Witold Szolginia. Tamten Lwów. - Wrozlaw, Wydawnictwo Wysoki Zamek,1992-1994), в якій автор, за рекомендаці-

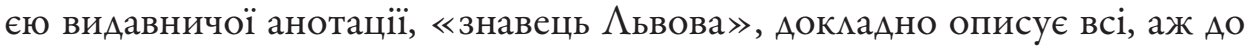

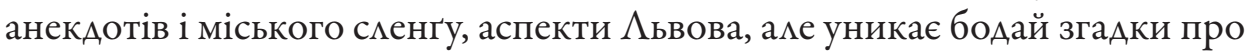
українську присутність у місті. І це Аише один приклад із багатьох.

Чи не єдиний виняток тут — «галицький/гуцульський текст» Станіслава Вінценза (1888-1971) ${ }^{1}$.

Вінценза з його земляками-колегами, які писали на ту ж, «галицьку», тему, зближує передовсім біографічний чинник: народження на карпатській земмі, у Слободі Рунгурській на Коломийщині, дитинство

${ }^{1}$ Аив. підсторінкову примітку 1 на с. 15. 
в польсько-українському етнічному та етнокультурному середовищі в Криворівні наА Черемошем, українка-няня Палагна, гімназії у Стриї та Коломиї, живе спілкування з мюдьми цього краю. Згадуючи про все це через багато років у післямові до першої книжки своєї тетралогії про Гуцульщину, Вінценз напише: «Ось такі мої витоки...». Тетралогію під назвою «На високій полонині» він почав писати 1931 р., в гуцульському селі Бистриця. Там він прожив до «золотого вересня» 1939-го, коли, якимсь Аивом звільнившись зі станіславської в'язниці, нелегально перейшов через гірський хребет Чорногору на Закарпаття, що на той час означало - в Угорщину, в еміграцію до кінця життя.

Що ж вілрізняє Вінценза від колег із «польського сегмента» (крім згаданих вище імен, назвімо попередників Вінценза - Я. Парандовського, Є. Стемповського, 3. Новаковського, сучасників - А. Ф. ОссенАовського, Ю. Віттліна, Є. Єнджеєвича, Ю. Аободовського)?

По-перше, галицька/гуцульська тема була в його творчості магістральною, практично єАиною. Аітературну Аіяльність Вінценз починав із журналістики, з перекладів Аостоєвського та Вітмена. Гуцульські спогади та враження увіходять до його творчості поступово, спочатку оформлюючись у вигляді нотаток та есеїв у періодиці, на середині життєвого шияху заволодіваючи ним цілком.

По-друге, Аля Вінценза Україна - це не об'єкт спогадів, утім, точніше буде сказати - не тільки такий об’єкт. У Вінценза концепт України/ Гуцульщини не позбавлений особистого ностальгійного відтіню, та при цьому він закорінений у фолькцорно-мітопоетичній свідомості.

I по-третє, головне: образ Гуцульщини створив поляк, однак жодного сліду національної обмеженості, нарочитого «поцьського» акценту, вузько, поготів негативно спрямованого проти когось, у змацюванні цього образу геть немає. Гуцульський компонент виступає як самодостатній, не залежний від сторонніх впливів і мінливих політичних обставин. У цьому відбилася відмінна осібність Вінцензової «польськості», Аля якої чужі національна пиха, возвеличення «свого» за рахунок «інакшого». В його «міті Гуцульщини» немає бездумного, поверхового захоплення, що його виявляє Аоброзичливий, але сторонній автор; Вінценз почувається «сином гуцульського краю», сприймає його як свою батьківщину. Чеслав Мілош згадував, що Аля Вінценза Гуцульщина була

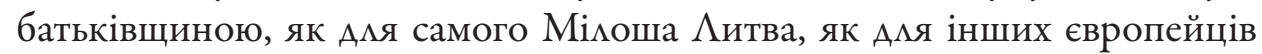
Уемьс, Бретань, Прованс, Каталонія, Країна басків, Трансимьванія [Аив.: 23, 70, 30, 33].

При цьому Гуцульщина була Аля письменника органічною частиною України - подібно як гуцульська говірка, що їі він усотав у дитинстві віА няні Палагни, сприймахася як українська. «...Мій твір був задуманий і 
відчутий по-українськи <...> по-гуцульськи», - писав Вінценз у мисті Ао свого українського кореспондента В. Полєка [цит. за: 27, 12-13].

Предметом проведеного вище аналізу були австро-українські та польсько-українські етнокультурні ситуації, пов' язані зі західною пограничною зоною України - Галичиною, почасти Волинню. Схожі й водночас вельми специфічні процеси відбувалися в таких етноісторичних областях, як Закарпаття (українсько-угорське культурне пограниччя) та Буковина (українсько-румунсько-польсько-єврейське пограниччя, т. зв. феномен буковинізму), також у східному та південно-східному регіонах (Харків, Аонбас, Приазов’я). Суттєвою Аля розуміння загацьноукраїнської культурної ситуації видається проблема українсько-єврейського культурного, передовсім мітературного, пограниччя. Ці теми потребують окремого розгяяду.

\section{МITEPATУPA}

1. Адельман Аж. Що таке глобальна історія сьогодні? - URL: http://www.historians.in.ua/ index.php/en/dyskusiya/2387-dzheremi-adelman-shcho-take-globalna-istoriya-sogodni

2. Андрухович Ю. Город-корабль // Вестник Европы, 2005. №13. С. 151-157.

3. Барабаш Ю. Карпатський вузол: до проблеми етнокультурного пограниччя (АеопольА фон Захер-Мазох, Станіслав Вінценз) // Слово і Час. 2015. №1. С. 3-16.

4. Белаш Н. Зона освоения (фронтир) и ее образ в американской и русской культурах // Общественные науки и современность. 1998. № 5. С. 75-89.

5. Брехуненко В. Козаки на Степовому Кордоні Європи: типологія козацьких спільнот XVI - першої половини XVII ст. Київ: Національна академія наук України, Інститут української археографії та Ажерелознавства ім. М. С. Грушевського, 2011. 504 с.

6. Брехуненко В. Фронтир // Енцикмопедія історії України: У 10 т. Київ: Наукова думка, 2013. T. 10. C. 335-337.

7. Бронісловас I. Концепція культури пограниччя // Культурологічний часопис «Ї». 1997. №10. C. $36-47$.

8. Вальденфельс Б. Топографія Чужого: студії до феноменології Чужого. Пер. з нім. В. Кебуладзе. Київ: ППС, 2002. 206 с.

9. Венера в мехах [Представление]. Работы о мазохизме. Захер-Мазох $\Lambda$., Аелёз Ж., Фрейд 3. Москва: РИК «Культура», Ad Marginem, 1992. 380 с.

10. Вушко I. Свої сереА чужих: австрійські чиновники та Галичина, 1772-1867 (книжка у шпаргалці). - URL: http://uamoderna.com/md/vushko-austrian-bureaucrats-galicia

11. Гаврилів T. На брамах Європи: $\Lambda$ ьвів та ідея Європи в Йозефа Рота. Інтертекст Аітературного Аьвова. // Парадигма. Збірник наукових праць. Випуск 4. Аьвів: Інститут українознавства ім. І. Крип'якевича НАН України, 2009. С.101-110.

12. Гінріхс Я. П. Lemberg-Lwówмав Аовгопалий. Київ: Видавництво Жупанського, 2010. 144 с.

13. Грабович Г. Мітологізація $\Lambda$ ьвова: відлуння присутності та відсутності // Грабович $Г$. Тексти і маски. Київ: Критика, 2005. С. 155-181.

14. Аашкевич Я. Большая граница Украины (этнический барьер или этноконтактная зона) // Этноконтактные зоны в европейской части СССР (География, динамика, методы изучения). Москва: Московский филиал географического общества СССР. 1989. С. 7-20.

15. Аашкевич Я. Етноніміка між наукою та політикою, або довкола національного імені українського народу // Дашкевич Я. «...Учи неможними устами казати правду». Історична есеїстика (1989-2008). Київ: Темпора, 2011. С. 88-95. 
16. Дашкевич Я. Україна на межі між сходом і заходом (XIV-XVIII ст.) // Записки наукового товариства ім. Т. Шевченка. Т. ССХXII. Праці історико-філософської секції. Аьвів, НТШ, 1991. С. 28-44.

17. Зимомря М. Карл-Емімь Францоз у контексті українсько-німецько- єврейських культурних взаємодій на змамі XIX ст. // Єврейська історія та культура в країнах Центральної та Східної Європи. Збірник наукових праць. Київ, 1998. С. 52-55.

18. Ісаєвич Я. Галичина у Габсбурзькій монархії: національно-політичні рухи і культурний плюралізм // Українська мітература в Австрії, австрійська - в Україні (матеріали міжнародного симпозіуму). Київ: Брама $\Lambda$ ТА, 1994. С. 163-171.

19. Каюк С.М. Запорозьке козацтво і Великий степовий кордон (Аруга половина XVIII — початок XIX ст.) // Четвертий міжнародний конгрес україністів. Історія. Ч.1. ОАеса, 1999. C. $241-246$.

20. Каюк C. Страсті за фронтиром, або Жіночий погляА на чоловічу дискусію. -URL: http://www.historians.in.ua/index.php/en/dyskusiya/2177

21. Аеп'явко С. Великий Кордон Європи як фактор становцення українського козацтва (XVI ст.). Запоріжжя: РА «Тандем-У», 2001.64 с.

22. Аеп'явко C. Українське козацтво і теорія Великого Кордону // Козацька спадщина. 2005. № 2. C. $14-18$.

23. Мілош Ч. Вемике князівство мітератури. Вибрані есеї. Київ: Аух і Аітера, 2011. 440 с.

24. Наливайко А. Очима Заходу. Рецепція України в ЗахіАній Європі XI-XVIII ст. Кийв: Основи, $1998.578 \mathrm{c.}$

25. Наливайко А. Українська тема в творчості К.-Е. Францоза // Франщоз К.-Е. За правду: Роман, повість, оповіАання / Пер. з нім.; прим. М. Зимомрі. Ужгород: Карпати, 1982. C. 5-22.

26. «Поверх кордону»: концепція прикордоння як об’єкт дослідження. // Україна модерна. 2011. Ч. 18. С. 47-78.

27. Полєк В. Калевала Гуцулів // Вінцензіана. Статті, Аисти, фрагменти творів. За редакцією Миколи Васильчука. Коломия, 2008. С. 12-22.

28. Рихло П. Український меридіан Карла Емімя Францоза // Франщоз К. E. Ukrainika. Культурологічні нариси. Упорядкування, переклад з німецької, передмова й коментар Петра Рихла. Чернівці: Книги - XXI, 2010. С. 7-17.

29. Рот Й. МанАрівка по Галичині // Культурологічний часопис «Ї». 1995. № 6. С. 42—47.

30. Сухомлинов О. Культурні пограниччя: новий погляА на стару проблему. Аонецьк: ЮгоВосток, 2008.212 c.

31. Цибенко А. Післямова // Захер-Мазох А. Вибрані твори. Аьвів: Аітопис, 1999. C. $363-383$.

32. Чижевський К. Культура і солідарність - URL: https://zbruc.eu/node/14906

33. Чижевський К. Аінія повернення. Про практику прикордоння у діалозі з Чеславом Міцошем. Аьвів: Кацьварія, 2013. 248 с.

34. Чорновол I. Компаративні фронтири. Світовий і вітчизняний вимір. Київ: Критика, $2015.376 \mathrm{c}$.

35. Bronsen D. Joseph Roth. Eine Biographie. Köln, Kiepenheuer \& Witsch, 1974. 713 s.

36. Dąbrowska-Partyka M. Literatura pogranicza. Pogranicze literatur. Kraków, Wydawnictwo UJ, 2004. $264 \mathrm{~s}$.

37. Deleuze G. et Guattari F. Rhizome, introduction. Paris: Edit de Minuit, 1976. 75 p.

38. Literary Galicia: from post-war to post-modern: a local guide to the global imagination / ed. By Adam Michajłow, Waldemar Pacławski. Kraków, Oficyna Literacka, 1991. 191 p.

39. Magris C. Der habsburgische Mythos in der modernen österreichischen Literatur. Wien, Paul Zsolnay Verlag, 2000. 414 s.

40. Uliasz S. O literaturze kresów i pograniczu kultur. Rozprawy i szkice. Rzeszów: Wydawnictwo Uniwersytetu Rzeszowskiego, 2001.218 s.

41. Vushko I. The Politics of Cultural Retreat: Imperial Bureaucracy in Austrian Galicia, 1772-1867. Yale University Press, 2015.328 p.

42. Waldenfels B. Topographie des Fremden. Studien zur Phänomenologie des Fremden. Frankfurt am Main Suhrkamp 1997.278 s. 
43. Zymomrja M. K. E. Franzos und sein Aufsatz über Taras Ševčenko // Zymomrja M. Deutschland und Ukraine: durch die Abrisse zur Wechselseitigkeit von Kulturen. Fürth/ Bayern, Flacius Verlag, 1999. S. 36-43.

Отримано 23 грудня 2019 р.

\section{REFERENCES}

1. Adelman, Dzh. (2018, February 04). Shcho take hlobalna istoriia sohodni? Hisrtorians Retrieved from: http://www.historians.in.ua/index.php/en/dyskusiya/2387-dzheremiadelman-shcho-take-globalna-istoriya-sogodni [in Ukrainian]

2. Andruhovich, Yu. (2005). Gorod-korabl' Vestnik Evropy, 13, 151-157. [in Russian]

3. Barabash, Yu. (2015). Karpatskyi vuzol: do problemy etnokulturnoho pohranychchia (Leopold fon Zakher-Mazokh, Stanislav Vintsenz) Slovo i Chas, 1, 3-16. [in Ukrainian]

4. Belash, N. (1998). Zona osvoeniya (frontir) i ee obraz v amerikanskoj i russkoj kul'turah Obshchestvennye nauki i sovremennost', 5, 75-89. [in Russian]

5. Brekhunenko, V. Kozaky na Stepovomu Kordoni Yevropy: typolohiia kozatskykh spilnot XVIpershoi polovyny XVII st. Kyiv: Natsionalna akademiia nauk Ukrainy, Instytut ukrainskoi arkheohrafii ta dzhereloznavstva im. M. S. Hrushevskoho, 2011. [in Ukrainian]

6. Brekhunenko, V. (2013). Frontyr In Entsyklopediia istorii Ukrainy (Vol. 1-10; Vol. 10), pp. 335-337. Kyiv: Naukova dumka. [in Ukrainian]

7. Bronislovas, G. (1997). Kontseptsiia kultury pohranychchia Kulturolohichnyi chasopys "I", 10,36-47. [in Ukrainian]

8. Valdenfels, B. (2002). Topohrafiia Chuzhoho: studii do fenomenolobii Chuzhoho. (V. Kebuladze, Trans.). Kyiv: PPS. [in Ukrainian]

9. Zaher-Mazoh, L., Delyoz, Zh. \& Frejd, Z. (1992). Venera v mekhah [Predstavlenie]. Rabotyo mazohizme. Moscow: RIK "Kul'tura”, Ad Marginem. [in Russian]

10. Vushko, I. (2015, October, 30). Svoi sered chuzhykh: avstriiski chynovnyky ta Halychyna, 1772-1867 (knyzhka u shparhaltsi) Retrieved from: http://uamoderna.com/md/vushkoaustrian-bureaucrats-galicia [in Ukrainian]

11. Havryliv, T. (2009). Na bramakh Yevropy: Lviv ta ideia Yevropy v Yozefa Rota. Intertekst literaturnoho Lvova. In Paradyhma. Zbirnyk naukovykh prats, 4, 101-110. Lviv: Instytut ukrainoznavstva im. I. Krypiakevycha NAN Ukrainy. [in Ukrainian]

12. Hinrikhs, Ya. P. (2010). Lemberg_Lwów-Lviv. Fatalne misto. Z niderlandskoi pereklav (Ya. Dovhopalyi, Trans.) Kyiv: Vydavnytstvo Zhupanskoho. [in Ukrainian]

13. Hrabovych, H. (2005). Mitolohizatsiia Lvova: vidlunnia prysutnosti ta vidsutnosti In Hrabovych, H. Teksty i masky, pp. 155-181. Kyiv: Krytyka. [in Ukrainian]

14. Dashkevich, Ya. (1989). Bol'shaya granica Ukrainy (etnicheskij bar'er ili etnokontaktnaya zona) In Etnokontaktnye zony $v$ evropejskoj chasti SSSR (Geografiya, dinamika, metody izucheniya), pp. 7-20. Moscow: Moskovskij filial geograficheskogo obshchestva SSSR. [in Russian]

15. Dashkevych, Ya. (2011). Etnonimika mizh naukoiu ta politykoiu, abo dovkola natsionalnoho imeni ukrainskoho narodu In Dashkevych, Ya. "...Uchy nelozhnymy ustamy kazaty pravdu”. Istorychna eseistyka (1989-2008), pp. 88-95. Kyiv: Tempora. [in Ukrainian]

16. Dashkevych, Ya. (1991). Ukraina na mezhi mizh skhodom i zakhodom (XIV_XVIII st.) In Zapysky naukovoho tovarystva im. T. Shevchenka, CCXXII. Pratsi istoryko-filosofskoi sektsii, 28-44. Lviv: NTSh. [in Ukrainian]

17. Zymomria, M. (1998). Karl-Emil Frantsoz u konteksti ukrainsko-nimetsko- yevreiskykh kulturnykh vzaiemodii na zlami XIX st. In Yevreiska istoriia ta kultura v krainakh Tsentralnoi ta Skbidnoi Yevropy. Zbirnyk naukovykh prats, pp. 52-55. Kyiv. [in Ukrainian]

18. Isaievych, Ya. (1994). Halychyna u Habsburzkii monarkhii: natsionalno-politychni rukhy i kulturnyi pliuralizm In Ukrainska literatura $v$ Avstrii, avstriiska $-v$ Ukraini (materialy mizhnarodnoho sympoziumu), pp. 163-171. Kyiv: Brama LTD. [in Ukrainian] 
19. Kaiuk, S.M. (1999). Zaporozke kozatstvo i Velykyi stepovyi kordon (druha polovyna XVIII - pochatok XIX st.) In Chetvertyi mizhnarodnyi konhres ukrainistiv. Istoriia. Ch.1, 241-246. Odesa. [in Ukrainian]

20. Kaiuk, S. (2017, May3). Strasti za frontyrom, abo Zhinochyi pohliad na cholovichu dyskusiiu. Hisrtorians Retrieved from: http://www.historians.in.ua/index.php/en/dyskusiya/2177 [in Ukrainian]

21. Lepiavko, S. (2001). Velykyi Kordon Yevropy yak faktor stanovlennia ukrainskoho kozatstva (XVIst.). Zaporizhzhia: RA “Tandem-U”. [in Ukrainian]

22. Lepiavko, S. (2005). Ukrainske kozatstvo i teoriia Velykoho Kordonu Kozatska spadshchyna, 2, 14-18. [in Ukrainian]

23. Milosh, Ch. (2011). Velyke kniazivstvo literatury. Vybrani esei. Kyiv: Dukh i litera. [in Ukrainian]

24. Nalyvaiko, D. (1998). Ochyma Zakhodu. Retseptsiia Ukrainy $v$ Zakbidnii Yevropi XI-XVIII st. Kyiv: Osnovy. [in Ukrainian]

25. Nalyvaiko, D. (1982). Ukrainska tema v tvorchosti K.-E.Frantsoza In Frantsoz, K.-E. Za pravdu: Roman, povist, opovidannia (M. Zymomria, Trans.), pp. 5-22. Uzhhorod: Karpaty. [in Ukrainian]

26. "Poverkh kordonu”: kontseptsiia prykordonnia yak obiekt doslidzhennia (2011). Ukraina moderna, 18, 47-78. [in Ukrainian]

27. Poliek, V. Kalevala Hutsuliv (2008). In (M. Vasylchuk, Ed.). Vintsenziana. Statti, lysty, frabmenty tvoriv, pp. 12-22. Kolomyia. [in Ukrainian]

28. Rykhlo, P. (2010). Ukrainskyi merydian Karla Emilia Frantsoza In Frantsoz, K. E. Ukrainika. Kulturolohichni narysy, 7-17. (Trans.) Rykhlo, P. (Ed.). Chernivtsi: Knyhy - XXI. [in Ukrainian]

29. Rot, Y. (1995). Mandrivka po Halychyni Kulturolohichnyi chasopys "I", 6, 42-47. [in Ukrainian]

30. Sukhomlynov, O. (2008). Kulturni pohranychchia: novyi pobliad na staru problemu. Donetsk: Yuho-Vostok. [in Ukrainian]

31. Tsybenko, L. (1999). Pisliamova In Zakher-Mazokh, L. Vybrani tvory, pp. 363-383. Lviv: Litopys. [in Ukrainian]

32. Chyzhevskyi, K. (2013, November 1). Kultura i solidarnist Zbruč Retrieved from: https:// zbruc.eu/node/14906 [in Ukrainian]

33. Chyzhevskyi, K. (2013). Liniia povernennia. Propraktyku prykordonnia u dialoziz Cheslavom Miloshem. Lviv: Kalvariia. [in Ukrainian]

34. Chornovol, I. (2015). Komparatyvni frontyry. Svitovyi i vitchyznianyi vymir. Kyiv: Krytyka. [in Ukrainian]

35. Bronsen, D. (1974).Joseph Roth. Eine Biographie. Köln: Kiepenheuer\& Witsch. [in German]

36. Dąbrowska-Partyka, M. (2004). Literatura pogranicza. Pogranicze literatur. Kraków: Wydawnictwo UJ. [in Polish]

37. Deleuze, G. \& Guattari, F. (1976). Rhizome, introduction. Paris: Edit de Minuit. [in French]

38. Michajłow, A. \& Pacławski,W. (Eds.) (1991). Literary Galicia: from post-war to post-modern: a local guide to the global imagination. Kraków: Oficyna Literacka.

39. Magris, C. (2000). Der habsburgische Mythos in der modernen österreichischen Literatur. Wien: Paul Zsolnay Verlag. [in German]

40. Uliasz, S. (2001). O literaturze kresów i pograniczu kultur. Rozprawy i szkice. Rzeszów: Wydawnictwo Uniwersytetu Rzeszowskiego. [in Polish]

41. Vushko, I. (2015). The Politics of Cultural Retreat: Imperial Bureaucracy in Austrian Galicia, 1772-1867. Yale University Press.

42. Waldenfels, B. (1997). Topographie des Fremden. Studien zur Phänomenologie des Fremden. Frankfurt am Main: Suhrkamp. [in German]

43. Zymomrja, M. (1999). K. E. Franzos und sein Aufsatz über Taras Ševčenko In Zymomrja, M. Deutschland und Ukraine: durch die Abrisse zur Wechselseitigkeit von Kulturen, 36-43. Fürth/ Bayern: Flacius Verlag. [in German]

Received 23 December 2019 
Yurii Barabash, doctor of philology, professor

A. M. Gorky Institute of World Literature

25a Povarskaya st., Moscow 121069

e-mail: barabash.yuri@gmail.com

ORCID 0000-0002-8938-9408

\section{ALIEN-DIFFERENT-ONE'S OWN. ETHNOCULTURAL FRONTIER: CONCEPTUAL, TYPOLOGICAL, AND SITUATIONAL ASPECTS}

This is the first paper of the three-issue series about the ethnocultural frontier planned by the author. A long time ago, the scholarly discussions on the problems of the frontier, which became quite vivid in the last decades, had overcome the initial relatively local frames of the American 'thesis of the frontier' connected with the specific conditions and circumstances of the Wild West epoch. Currently, these discussions cover various fields of humanities and are becoming more relevant at the present stage of the global historical development, as they signal new civilizational traits and specific features of this stage. By this, the author implies globalization and glocalization processes that encompass multiplicity and variability, also unpredictability, oddity, and non-stability of combinations as well as the diversity of ambivalent forms and transitive states emerging on this basis. The paper defines key theoretical and methodological principles forming the intentional (according to R. Carnap) approach to the concept of the frontier; it also suggests a number of typological models of the ethnocultural frontier (frontier literary zones; transitive periods and states in the historicalliterary process, as well as in the language sphere, in creative work, and psychology of an author; comparative collations, etc.). Finally, it analyzes selected literary cases that emerged in geopolitical and ethnocultural zones of Ukraine (namely Austro-Ukrainian and PolishUkrainian frontiers) within the framework 'Alien - Different - One's own'. The analysis, both diachronic and synchronic, considers contextual factors, i.e. genetic, historical, geopolitical, international, ideological, and sociocultural contexts. In the following two papers of the series, the author intends to deal with the eastern ethno- and linguocultural frontier of Ukraine (Kharkiv, Donbas) and the Ukrainian-Jewish literary frontier.

Keywords: frontier, concept, context, ethnocultural zone, typology, model, Alien-DifferentOne's Own. 